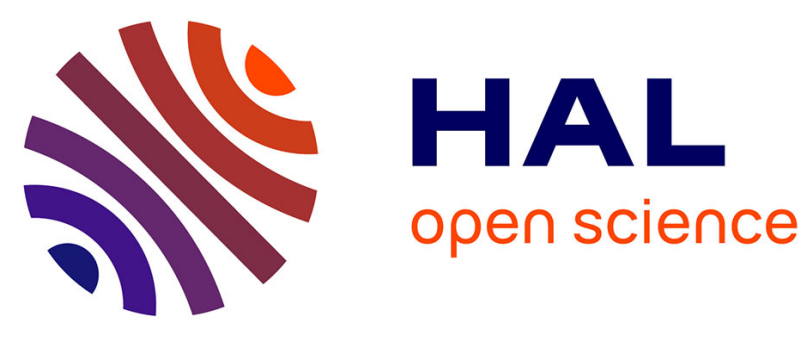

\title{
Magmatic cycles pace tectonic and morphological expression of rifting (Afar depression, Ethiopia)
}

S. Medynski, Raphaël Pik, Pete Burnard, S Dumont, Raphael Grandin, Alice Williams, Pierre-Henri Blard, Irene Schimmelpfennig, C Vye-Brown, Lyderic France, et al.

\section{To cite this version:}

S. Medynski, Raphaël Pik, Pete Burnard, S Dumont, Raphael Grandin, et al.. Magmatic cycles pace tectonic and morphological expression of rifting (Afar depression, Ethiopia). Earth and Planetary Science Letters, 2016, 446, pp.77-88. 10.1016/j.epsl.2016.04.014 . hal-01469912

\section{HAL Id: hal-01469912 \\ https://hal-amu.archives-ouvertes.fr/hal-01469912}

Submitted on 22 Feb 2017

HAL is a multi-disciplinary open access archive for the deposit and dissemination of scientific research documents, whether they are published or not. The documents may come from teaching and research institutions in France or abroad, or from public or private research centers.
L'archive ouverte pluridisciplinaire HAL, est destinée au dépôt et à la diffusion de documents scientifiques de niveau recherche, publiés ou non, émanant des établissements d'enseignement et de recherche français ou étrangers, des laboratoires publics ou privés. 


\title{
Magmatic cycles pace tectonic and morphological expression of rifting (Afar depression, Ethiopia)
}

\author{
S. Medynski ${ }^{\mathrm{a}, *, 1}$, R. Pik ${ }^{\mathrm{a}}$, P. Burnard ${ }^{\mathrm{a}, 2}$, S. Dumont ${ }^{\mathrm{b}}$, R. Grandin $^{\mathrm{c}}$, A. Williams ${ }^{\mathrm{a}}$, \\ P.-H. Blard ${ }^{\text {a }}$, I. Schimmelpfennig ${ }^{\text {d }}$, C. Vye-Brown ${ }^{\text {e }}$, L. France ${ }^{\mathrm{a}}$, D. Ayalew ${ }^{\mathrm{f}}$, L. Benedetti ${ }^{\mathrm{d}}$, \\ G. Yirgu ${ }^{\mathrm{f}}$, ASTER team ${ }^{\mathrm{b}, 3}$
}

\footnotetext{
a CRPG, UMR 7358 CNRS - Université de Lorraine, 15 rue Notre Dame des Pauvres, BP 20, 54500 Vandoeuvre-lès-Nancy, France

${ }^{\mathrm{b}}$ Nordic Volcanological Center, Institute of Earth Sciences, University of Iceland, Reykjavik, Iceland

c Institut de Physique du Globe de Paris, Sorbonne Paris Cité, Univ Paris Diderot, CNRS, F-75005 Paris, France

${ }^{\mathrm{d}}$ Aix-Marseille Université, CNRS-IRD UM 34 CEREGE, Technopôle de l'Environnement Arbois-Méditerranée, BP80, 13545 Aix-en-Provence, France

e BGS, Murchison House, West Mains Road, Edinburgh, EH9 3LA, United Kingdom

${ }^{\mathrm{f}}$ School of Earth Sciences, Addis Ababa University, PO Box 1176, Addis Ababa, Ethiopia
}

Keywords:

tecto-magmatic processes cosmogenic isotopes Afar

\begin{abstract}
The existence of narrow axial volcanic zones of mid-oceanic ridges testifies of the underlying concentration of both melt distribution and tectonic strain. As a result of repeated diking and faulting, axial volcanic zones therefore represent a spectacular topographic expression of plate divergence. However, the submarine location of oceanic ridges makes it difficult to constrain the interplay between tectonic and magmatic processes in time and space. In this study, we use the Dabbahu-Manda Hararo (DMH) magmatic rift segment (Afar, Ethiopia) to provide quantitative constraints on the response of tectonic processes to variations in magma supply at divergent plate boundaries. The DMH magmatic rift segment is considered an analogue of an oceanic ridge, exhibiting a fault pattern, extension rate and topographic relief comparable to intermediate- to slow-spreading ridges. Here, we focus on the northern and central parts of DMH rift, where we present quantitative slip rates for the past $40 \mathrm{kyr}$ for major and minor normal fault scarps in the vicinity of a recent (September 2005) dike intrusion. The data obtained show that the axial valley topography has been created by enhanced slip rates that occurred during periods of limited volcanism, suggestive of reduced magmatic activity, probably in association with changes in strain distribution in the crust. Our results indicate that the development of the axial valley topography has been regulated by the lifetimes of the magma reservoirs and their spatial distribution along the segment, and thus to the magmatic cycles of replenishment/differentiation $(<100 \mathrm{kyr})$. Our findings are also consistent with magma-induced deformation in magma-rich rift segments. The record of two tectonic events of metric vertical amplitude on the fault that accommodated the most part of surface displacement during the 2005 dike intrusion suggests that the latter type of intrusion occurs roughly every 10 kyr in the northern part of the DMH segment.
\end{abstract}

\section{Introduction}

The variability of magma production in the mantle and subsequent transfers of magma to the crust, and potentially the surface, are fundamental, first-order controls on the style and morphol-

\footnotetext{
* Corresponding author.

E-mail address: medynski@ucdavis.edu (S. Medynski).

1 Now at University of California Davis.

2 Deceased.

3 ASTER Team: Maurice Arnold, Georges Aumaître, Didier Bourlès, Karim Keddadouche.
}

ogy of mid-ocean ridges (MOR) (MacDonald and Atwater, 1978; Carbotte et al., 2001; Macdonald, 2001; Macdonald et al., 2005). Few quantitative constraints exist on how magmatic and tectonic processes are coupled via dyke injection and fault slip in such a way as to maintain crustal accretion and produce typical axial morphologies along a magmatic rift at the scale of a few to tens of thousands of years (White et al., 2006; Standish and Sims, 2010; Grandin et al., 2012). The building of ridge topography results from competition between tectonic activity, which creates the topography via normal faulting, and magmatic activity, which tends to erase the topography by filling the growing depression with volcanic products (Behn et al., 2006). Many stud- 
ies have documented the contributions of diking and faulting to the extension process (most notably in Iceland), on both longterm (Mastin and Pollard, 1988; Forslund and Gudmundsson, 1991) and short-term timescales (Rubin, 1992; Gudmundsson, 2003; Doubre and Peltzer, 2007; Calais et al., 2008; Biggs et al., 2009; Dumont et al., 2016). However, an important yet unaddressed issue is the quantification of this tectonic activity in terms of variations in magmatic activity in the long term. In particular, is the tectonic activity constant through time or, on the contrary, is it related to the magmatic processes?

To address this question, we examine the subaerial Dabbahu/ Manda-Hararo (DMH) Afar active magmatic rift segment (Ethiopia, Fig. 1A), which represents a natural laboratory for investigating topographic evolution in response to complex magmatic and tectonic interactions at divergent plate boundaries. Although the DMH rift segment is currently at the ocean-continent transition stage, its morphology and extension rates are comparable to those of intermediate to slow-spreading ridges, suggesting that the same processes are at work in the two settings.

The $\sim 55 \mathrm{~km}$ long DMH rift segment in Central Afar is characterised by a narrow axial graben $(\sim 3 \mathrm{~km})$ flanked by $<100 \mathrm{~m}-$ high fault scarps. The total relief of the axial valley is $<300 \mathrm{~m}$ at the DMH rift, typical of intermediate- to slow-spreading MOR morphologies and similar to that observed in Iceland. (Fig. 1, Gudmundsson, 2005.) Four magmatic reservoirs have been identified along the DMH segment (Fig. 1) (Grandin et al., 2009; Wright et al., 2006, 2012; Ebinger et al., 2008; Barisin et al., 2009; Field et al., 2012): two axial magmatic centres at the northern end of the segment; one below Dabbahu volcano; and one midway along the length of the segment, referred to as the mid-segment magma chamber (MSMC). Dabbahu and the MSMC both possess a shallow reservoir that is connected to a deeper reservoir below $15 \mathrm{~km}$ depth (Grandin et al., 2010b; Field et al., 2012). The shallow Dabbahu magma storage area may consist of a series of stacked sills at 1 to $5 \mathrm{~km}$ depth (Field et al., 2012). In addition, two magmatic reservoirs are located off-axis: Gabho volcano (in the north-east) and the Durrie volcanic centre (in the west) (Fig. 1). In September 2005, a major intrusion ruptured the entire length of the $\mathrm{DMH}$ rift, initiating a 5-yr-long rifting episode that involved 13 further smaller dike intrusions and that highlighted complex magmatic interactions between three of the magmatic centres: Dabbahu, Gabho and the MSMC (Wright et al., 2012; Grandin et al., 2010a, 2010a; Hamling et al., 2009). The major dike that initiated the crisis was modelled to be 60 to $70-\mathrm{km}$-long, $\sim 1-2 \mathrm{~km}^{3}$ intrusion and produced $4 \mathrm{~m}$ of average regional horizontal opening (Wright et al., 2012, 2006; Grandin et al., 2009). Thirteen subsequent and smaller dikes $\left(\sim 0.1 \mathrm{~km}^{3}\right.$ each) were intruded between 2005 and 2010, all emitted from the MSMC and producing a lesser degree of deformation (Buck, 2006; Hamling et al., 2009; Grandin et al., 2010a, 2010b; Belachew et al., 2011; Wright et al., 2012). The transfer of magma to shallow depths activated numerous surface faults and fissures along the length of the dike intrusion (Fig. 2A, Rowland et al., 2007; Wright et al., 2006; Grandin et al., 2009; Dumont et al., 2016). The ground displacement associated with this first dike intrusion was too large in the near-field discriminate the role of individual faults using geodetic approaches (Wright et al., 2006; Grandin et al., 2009). However, the modelling of Grandin et al. (2009) and, more recently, the analysis of surface fault displacements during inter-diking periods between 2005 and 2010 at the DMH rift segment (Dumont et al., 2016) suggest that only faults dipping toward the dike were able to release the dike-induced stresses. In the DMH rift segment, a substantial opening component also prevails, but no evidence for reverse faulting has been identified. Similar phenomena have also been observed in Iceland during the Krafla crisis
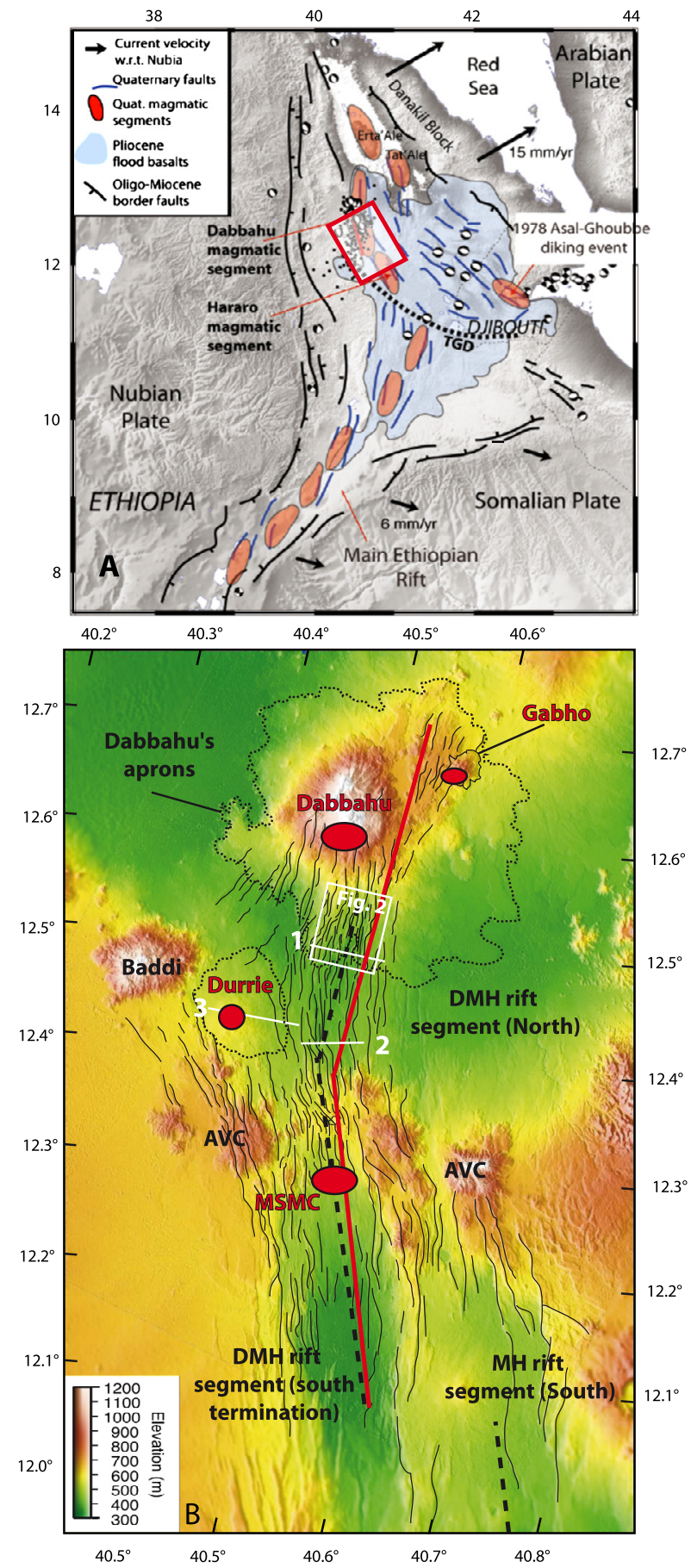

Fig. 1. Regional geological setting. A: Regional setting of the Afar Rift and location of the Dabbahu/Manda Hararo segment - modified after (Ebinger et al., 2008). B: Dabbahu/Manda Hararo rift magmatic complexes and fault pattern. The black dotted line shows the principal rift axis, defined as the lowest point of the depression. White lines labelled 1, 2 \& 3 correspond to the topographic sections in Fig. 4. The red line indicates the location of the 2005 dyke intrusion and fault zone reactivation. Note that the September 2005 dike (red line) did not intrude on the alignment of the rift axis, but deviated slightly to the east, below the rift shoulder. Red circles indicate the different magma bodies, located below the Dabbahu and the Gabho volcanoes, and at the mid-axis: the mid-segment magma chamber (MSMC) and the slightly off-axis Durrie volcano. The main study areas are the following: one crosssection located at the contact of the axial depression with the segment-tip volcano of Dabbahu (profile 1), and two cross-sections located at the mid-length of the segment, ranging from the mid-axis to the recent (15 ka; Medynski et al., 2015) slightly off-axis Durrie volcanic centre (profiles 2 and 3). (For interpretation of the references to colour in this figure legend, the reader is referred to the web version of this article.) 


\section{B. Deformation associated with the}

\section{A. Geological map}

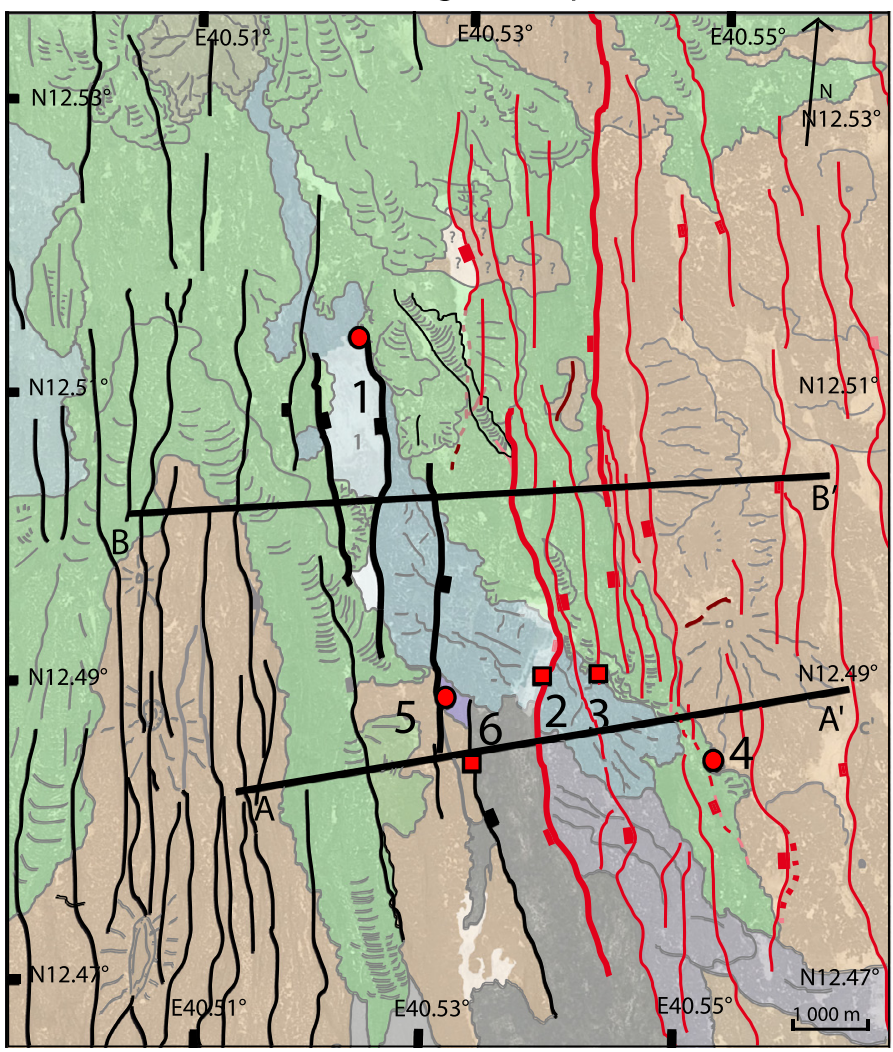

1: Yemaryurgle fault (sample Yem7)

2: Gabbole fault (samples Gab A)

3: Dik-3 fault (samples Dik3)

4: Dikika-1 fault (sample Dik-2)

5: Sample Gab G

6: Gab-B fault

\section{September 2005 dike intrusion in} the northern end of the DMH rift

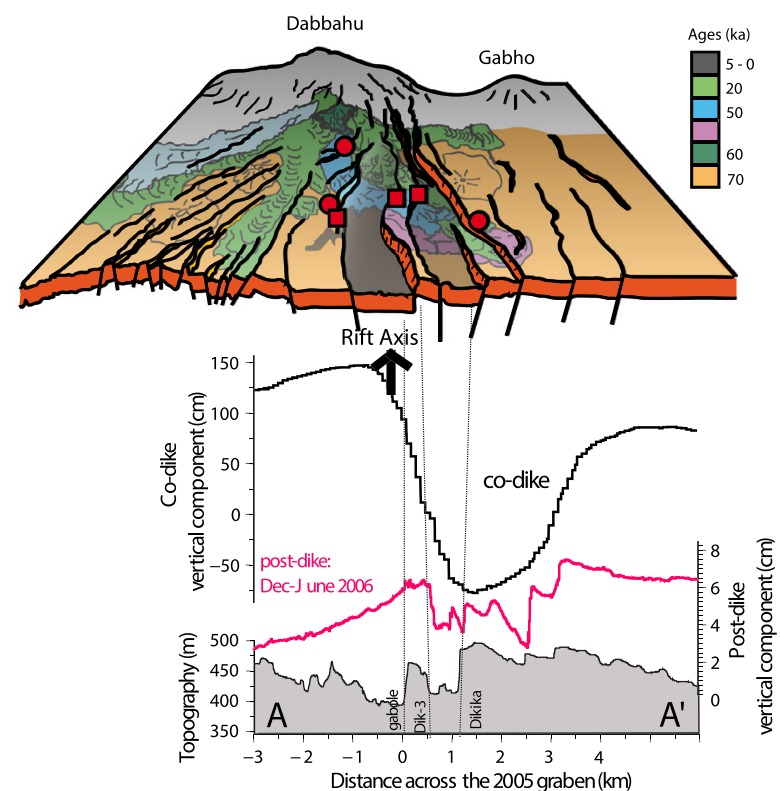

Limit of the reactivation corridor induced by the 2005 dike intrusion

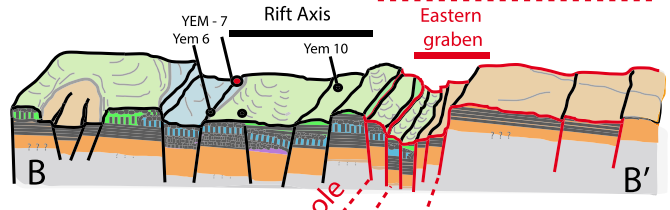

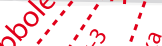

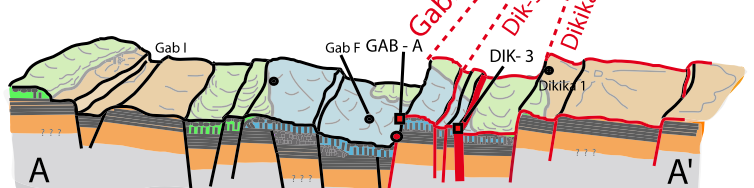

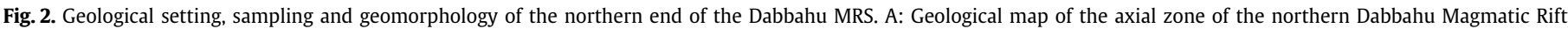

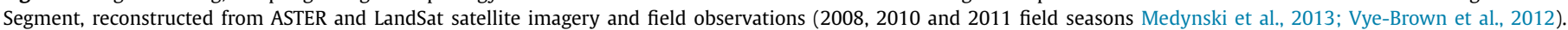

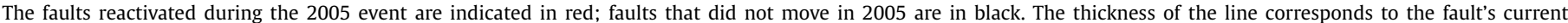

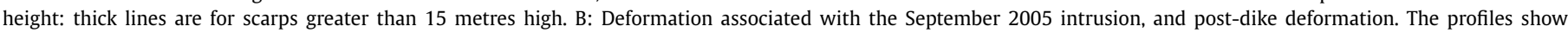

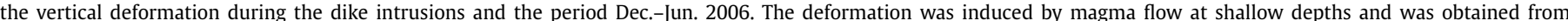

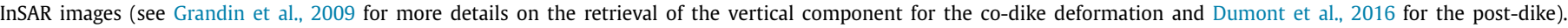

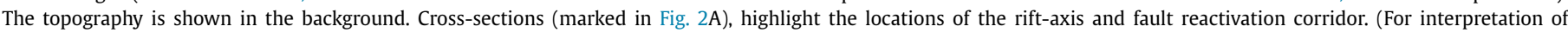
the references to colour in this figure legend, the reader is referred to the web version of this article.)

(1974-1985) (Brandsdottir and Einarsson, 1979; Einarsson, 1991; Sigmundsson et al., 2015).

Detailed studies of the tectonic and magmatic processes involved in the rifting episode were conducted over the decade that followed (see for example, Wright et al., 2006; Rowland et al., 2007; Ebinger et al., 2008; Ayele et al., 2009; Barisin et al., 2009; Hamling et al., 2009; Grandin et al., 2009, 2010a, 2010b, 2012; Keir et al., 2011; Wright et al., 2012). The major September 2005 dike was remarkable in that it did not intrude the main rift axis but was instead emplaced under the eastern rift shoulder at its northern end (Fig. 1B). This off-axis position appears to have resulted from the primary involvement of Dabbahu and Gabho reservoirs, with the MSMC coming into play only later (Fig. 1B; Wright et al., 2006; Ayele et al., 2009; Grandin et al., 2009). In the northern part of the segment, the September 2005 intrusion reactivated faults to the east of the central graben Fig. 1B and Fig. 2 (Ebinger et al., 2010). In a cross-section along the rift in the northern part of the segment, the associated deformation appears to correlate inversely with the rift segment topography (Fig. 2B); the highest amount of scarp activation occurred on the rift shoulders while no (or only limited) faulting was recorded at the rift axis where the depression is greatest.

Although not all dike intrusions will provoke a topographic response at the surface (Gudmundsson and Philipp, 2006; Froger et al., 2004), those that can cause fault reactivation must actively participate in the building of topography as diking is now considered the principal mode of accommodating extension in magma-rich rift segments such as those in Afar (Rubin and Pollard, 1988; Behn et al., 2006; Buck, 2006). In this study, we use terrestrial cosmogenic nuclide (TCN) dating (Gosse and Phillips, 2001; Medynski et al., 2013) to integrate the first, major dike intrusion of the 2005-2010 rifting crisis into the long-term topographical development of the DMH rift segment and to investigate the relationships between faulting events and magmatic differentiation and eruption timescales. The advantage of this dating technique is that it allows the timing of both volcanic and fault-slip events to be constrained (Gosse and Phillips, 2001; Palumbo et al., 2004). A key objective of the study is to quantify the long-term (100-kyr 

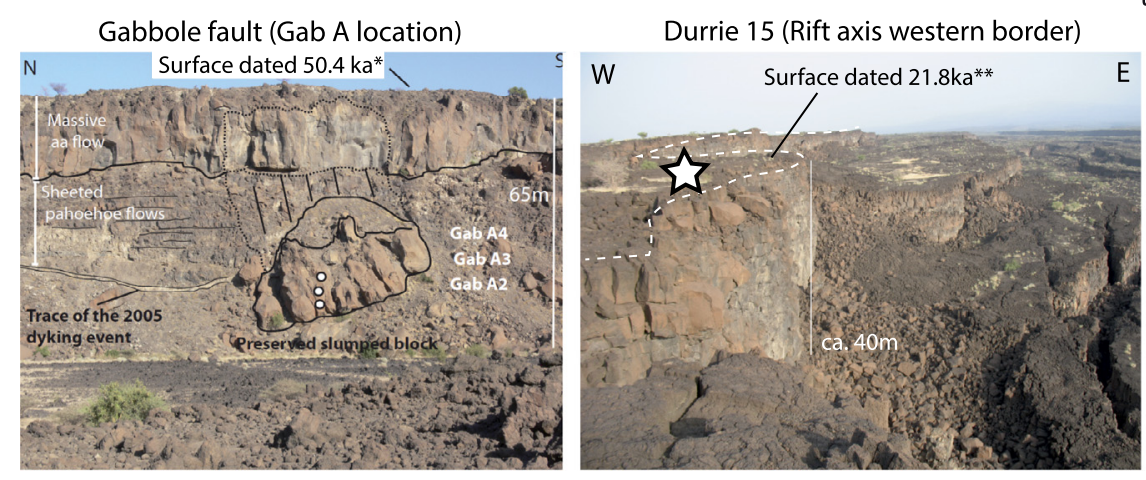

Morphological evidence of the topographic control by the Dikika- 1 fault on the lavas of the Dabbahu volcano

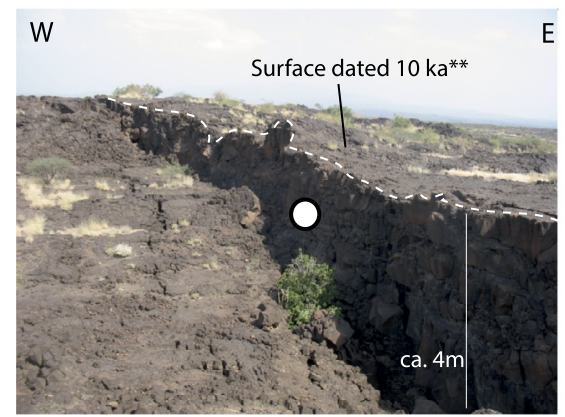

Durrie 10 (Western off-axis volcano)

*: Medynski et al., 2013

**: Medynski et al., 2015

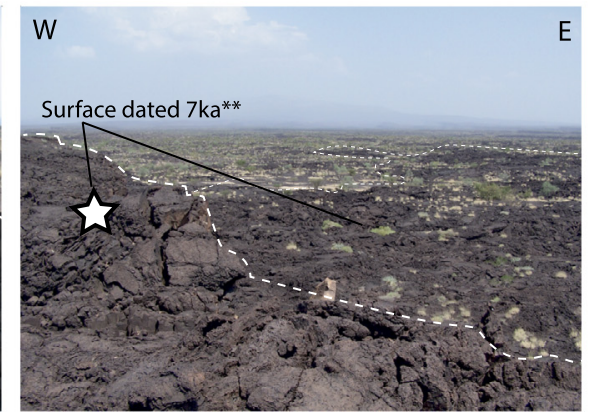

Durrie 16 (Rift axis)
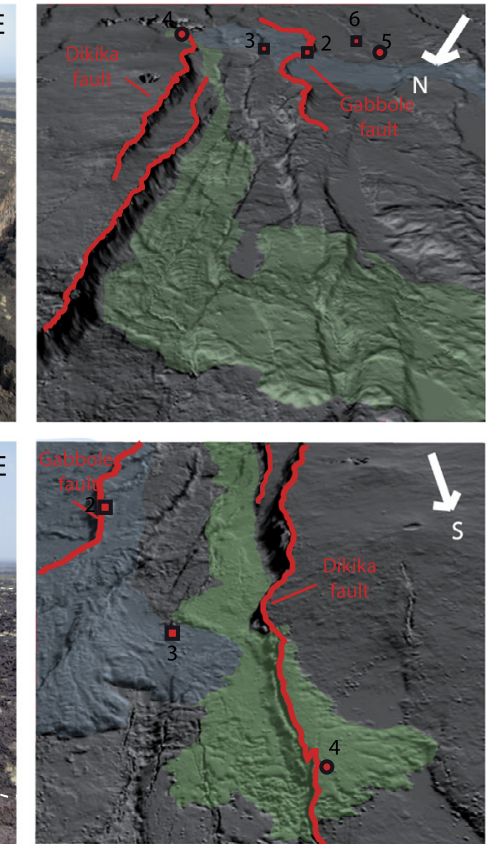

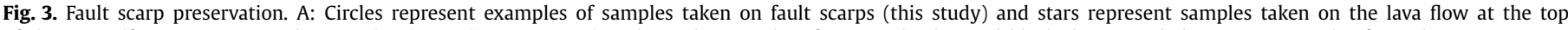

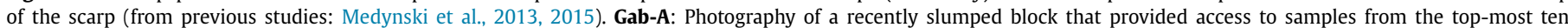

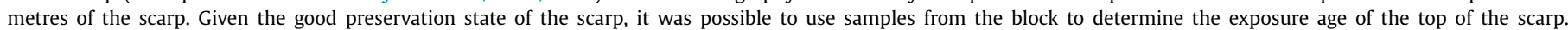

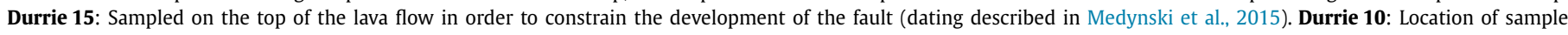

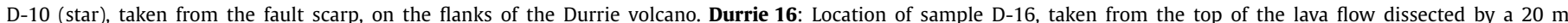

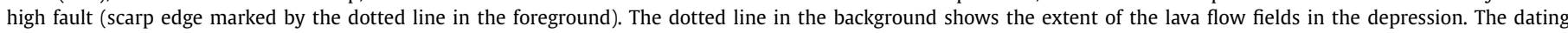

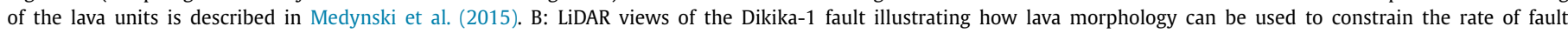

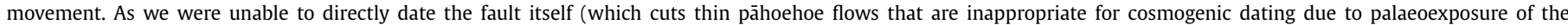

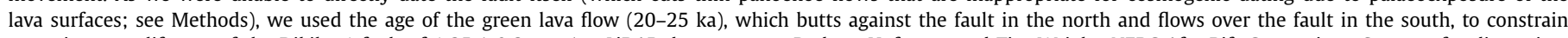

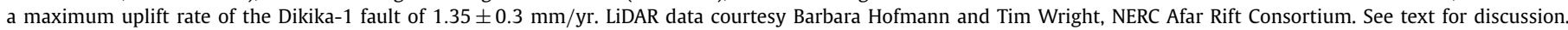
(For interpretation of the references to colour in this figure legend, the reader is referred to the web version of this article.)

timescale) dike-induced topographic surface displacement in order to better understand its coupling with magmatic activity.

\section{Methods}

\subsection{Terrestrial cosmogenic nuclides and scarp dating}

Terrestrial cosmogenic nuclides (TCN) provide a robust technique for determining chronologies in a variety of geological settings (see reviews in Gosse and Phillips, 2001; Niedermann, 2002; Dunai and Wijbrans, 2000). The technique requires the perfect preservation of surfaces (the fault scarps and the lava surfaces in this study) as removal (even partial) of the surface where most of the TCN accumulate will induce a bias in the age estimation. The low rainfall and erosion in the Afar present ideal conditions for surface preservation (Fig. 2) and thus TCN exposure dating (Gosse and Phillips, 2001).

TCN concentrations along tectonic scarps in volcanic environments have two origins: TCN accumulation through the lava surface (i.e., since the emplacement of the lava flow); and accumulation through the vertical face of the scarp itself (i.e., since scarp rupture). Special care must be taken to evaluate the relative contributions of these two components, either by dating the lava flow emplacement or by sampling the scarp at sufficient depth relative to the lava-top in order to avoid surface-exposure contamination (TCN production is negligible below depths of $4-5 \mathrm{~m}$ ). It is therefore easier to date scarps that dissect relatively thick (up to
$20 \mathrm{~m}$ in this area) massive ' $\mathrm{a}$ ' $\mathbf{a}$ flows than those that dissect the pāhoehoe flow units (usually 1 to $4 \mathrm{~m}$ thick), where it is impossible to assess potential cosmogenic inheritance between the emplacement of two successive flow units. All samples in this study were therefore taken at least $1.5 \mathrm{~m}$ below the top of the scarp in order to ensure dating of the scarp exposure alone and to avoid any bias caused by lava top exposure. The maximum contamination from the flow tops was $3 \%$, which is negligible compared to the measurement uncertainties. Sample location and site details are given Figs. 2 and 3, and cosmogenic details are given in Table 1 .

\subsection{Cosmogenic ${ }^{3}$ He production rate}

For this study, we used a local production rate determined by cross-dating using $\mathrm{Ar}-\mathrm{Ar}$ and cosmogenic ${ }^{3} \mathrm{He}$ techniques and previously published in Medynski et al. (2013). In that study, the compilation of Goehring et al. (2010) provided a good agreement with $\mathrm{Ar}-\mathrm{Ar}$ ages, but was unable to take into account the paleomagnetic evolution necessary to conserve consistency between the two methods of dating, and a local production rate was therefore calculated.

The calculation of the reference ${ }^{3} \mathrm{He}$ production rate $\left(P_{3 \text { local }}\right)$ scaled to sea-level high-latitude is given by:

$P_{3 \text { local }}=\frac{\left[{ }^{3} \mathrm{He}_{G a b D}\right]}{\left(A g e_{\mathrm{Ar}-\mathrm{Ar}}\right) * f * \text { Correc }_{\text {prof }} * \text { Correc }_{\text {magnetic }}}$ 
Table 1

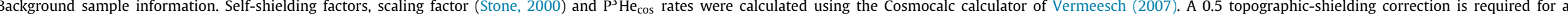
vertical surface.

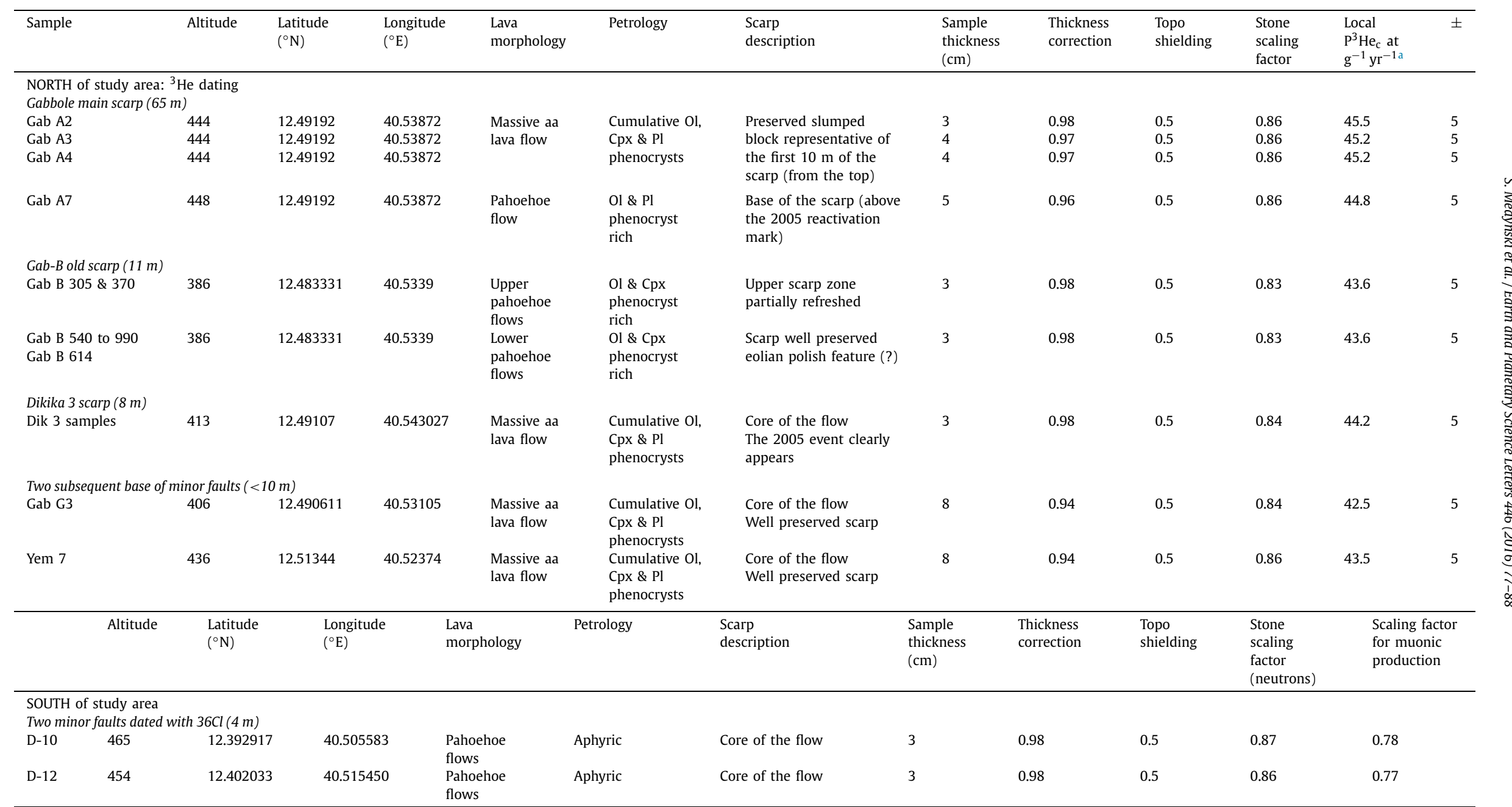

a The production rates applied to each sample were calculated using a local ${ }^{3} \mathrm{He}$ production rate of $108 \mathrm{at} / \mathrm{g} / \mathrm{yr}$. 
where $\left[{ }^{3} \mathrm{He}_{G a b D}\right]$ is the concentration in at/g of cosmogenic ${ }^{3} \mathrm{He}$ determined in sample $G a b-D, A g e_{\mathrm{Ar}-\mathrm{Ar}}$ is the $\mathrm{Ar}-\mathrm{Ar}$ age determined for the $G a b-D$ sample, $f$ is the Stone correction factor (Stone,

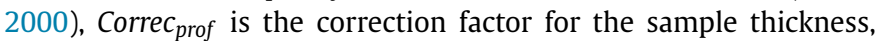
and Correc $_{\text {magnetic }}$ is the correction factor due to paleomagnetic variations (Stone, 2000). $P_{3 \text { local }}=108 \pm 12$ at $/ \mathrm{g} / \mathrm{yr}$.

This local production rate is lower than the rates published in (Blard et al., 2013) but is consistent with recent local production global mean calculated at the Fogo Islands (86-109 at/g/yr; Foeken et al., 2009) at similar latitude $\left(14.9^{\circ} \mathrm{N}\right.$ at Fogo; $12^{\circ} \mathrm{N}$ in this study).

The cosmogenic ages of all samples presented in Supplementary Material No. 3 \& 4 were calculated using:

Age $=\frac{\left(\frac{\left[{ }^{3} \mathrm{He}\right]}{P_{3 \text { local }} * f * \text { Corr }_{\text {prof }}}\right)}{\text { Corr }_{\text {magnetic }}}$

Cosmogenic ${ }^{3} \mathrm{He}$ was measured on separated olivine and pyroxene grains in the Noble Gas Laboratory at CRPG, by heating to $1300^{\circ} \mathrm{C}$ under vacuum following the methods described in Medynski et al. (2013). For more details see Supplementary Materials 5.

\subsection{Cosmogenic ${ }^{36} \mathrm{Cl}$}

The TCN ${ }^{36} \mathrm{Cl}$ is applicable to timescales of $\sim 10^{3}$ to $>10^{6} \mathrm{yr}$ (Dunai and Wijbrans, 2000). It has been extensively used for dating surfaces with carbonate lithologies (including fault scarps; Palumbo et al., 2004) as calcium is one of the main target elements for the in situ production of ${ }^{36} \mathrm{Cl}$ (besides potassium). A few studies have also used ${ }^{36} \mathrm{Cl}$ measurements in volcanic whole rocks to date the emplacement of lava flows (Zreda et al., 1993) and to calibrate TCN production rates (Licciardi and Pierce, 2008). Although pure Ca- and K-bearing minerals, such as feldspars, are preferred for ${ }^{36} \mathrm{Cl}$ dating because of their simpler chemical composition compared to whole rocks (Zreda et al., 1993; Licciardi and Pierce, 2008; Schimmelpfennig et al., 2009, 2011), the lack of sufficient phenocrysts in the lavas studied often imposes the use of whole-rock samples. In this study, the sampled lavas present aphyric or microlithic textures, preventing the use of separated mineral phases for exposure dating. We therefore used whole-rock ${ }^{36} \mathrm{Cl}$ analysis in order to estimate the exposure ages of the scarps. Cosmogenic ${ }^{36} \mathrm{Cl}$ was measured at the ASTER facility at CEREGE, following the methods described in Medynski et al. (2015). See Supplementary Material 4 and 5 for details.

\section{Long-term fault slip rates and the building of topography}

Building of axial depression topography over the long term ( $\sim 100 \mathrm{kyr}$ timescale) can be constrained using (i) the slip rates of the major faults (determined here from cosmogenic ${ }^{3} \mathrm{He}$ or ${ }^{36} \mathrm{Cl}$ exposure ages on the escarpments), and (ii) dating of lava flows emplaced along the rift since $60 \mathrm{ka}$, in order to estimate average slip rates (Medynski et al., 2013, 2015).

The two major tectonic features of the northern DMH rift (section 1 on Fig. 1 and Fig. 4) are the Gabbole and Dikika-1 faults (Fig. 3). These are synthetic west-dipping faults that offset the rift floor by 55 and $30 \mathrm{~m}$, respectively, at the sampling sites (Figs. 3A and 4), and constitute the eastern boundary of the main axial depression. In the axial valley and on the western flank, topography is distributed along a succession of smaller scarps $(<20 \mathrm{~m})$ such as the Gab-B site (Fig. 3 and SOM 1). The slip rates on the two boundary faults (Fig. 4) were constrained as follows. The Gabbole fault cuts a 51.1 ka lava flow which implies a minimum average vertical slip rate of $\mathbf{1 . 1} \pm 0.5 \mathrm{~mm} / \mathrm{yr}$ (SOM 1). Additionally, the scarp itself was dated ten metres below the top of the fault with ages ranging from 19 to $29.5 \mathrm{ka}$ (Fig. 4A and SOM 1-3 for details), with the oldest age providing the minimum exposure duration of this upper portion of the fault. This corresponds to a maximum vertical slip rate of $\mathbf{1 . 5} \pm 0.1 \mathrm{~mm} / \mathrm{yr}$ (Fig. 4A), hence at $29.5 \mathrm{ka}$ at least $10 \mathrm{~m}$ of the present-day axial depression had already been built. Similarly, the southern end of the Dikika-1 fault cuts a flow unit dated at 20-25 ka (Medynski et al., 2013) at a point where the scarp is $30 \mathrm{~m}$ high, and therefore has an average vertical slip rate of $\mathbf{1 . 3 5} \pm 0.15 \mathrm{~mm} / \mathrm{yr}$. Field relations indicate that the fault propagated southwards (Fig. 3) and initiated north of our sampling location. Assuming a mean constant slip rate of $1.5 \pm 0.1 \mathrm{~mm} / \mathrm{yr}$, then this system of fault scarps first initiated at $37.6 \pm 2.7 \mathrm{ka}$ (Fig. 4A). To constrain the slip rates that affected the western margin of the axial depression, three small $(<15 \mathrm{~m})$ faults (Gab-G3, Yem-7 and Gab-B) were dated. The Gab-G3 and Yem-7 scarps (sampled 1 and $1.5 \mathrm{~m}$ above the present ground level, respectively) display exposure ages of $8.4 \pm 0.9 \mathrm{ka}$ and $\mathbf{2 1 . 7} \pm 2.5 \mathrm{ka}$, corresponding to significantly lower average vertical slip rates of $0.18 \pm 0.02$ and $0.07 \pm 0.01 \mathrm{~mm} / \mathrm{yr}$, respectively, compared to the major scarps. The Gab-B fault cuts an older volcanic unit emplaced at $72.1 \pm 4.3 \mathrm{ka}$ (Medynski et al., 2013) (SOM 1). Thus, small $(<15 \mathrm{~m})$, rarely reactivated faults with low average slip rates exist in this northern part of the axial graben. The difference in the slip rates of the major and minor faults combined with the asymmetric rift axis topography (Fig. 4A) suggest that the deformation is not uniformly distributed across the northern part of the segment.

In the central part of the DMH segment, closer to the MSMC (section 2 on Fig. 1 and SOM 1), the ages of lava flows offset by faults (30 to $6.4 \mathrm{ka}$, Medynski et al., 2013, 2015) can also be used to estimate slip rates on the main faults. Here, the axial graben is symmetrical, with antithetic faults that exhibit mean vertical slip rates of 1.3 to $1.6 \mathrm{~mm} / \mathrm{yr}$ (Fig. 4B). These values are close to those of the major faults in the northern DMH segment over the same period of activity, suggesting common reactivation mechanisms in the northern and central parts of the segment. However, unlike in the northern part of the segment, the topography (and slip rates) across the central part is/(are) symmetrical (Fig. 4B), suggesting that the mechanisms are uniformly distributed here. Additionally, one of these faults displaces a younger flow (6.4 ka, Medynski et al., 2015) by over $20 \mathrm{~m}$, resulting in a higher mean slip rate of 2.8 $\mathrm{mm} / \mathrm{yr}$ that suggests that faulting may have increased recently (i.e. after $6.4 \mathrm{ka}$ ).

The most recent active volcanism in the central part of the DMH rift segment occurs outside the axial depression, centred on the 15-5 ka Durrie Volcanic Complex (SW of the Dabbahu volcano, spreading from the axis up to $15 \mathrm{~km}$ to the west) (Medynski et al., 2015). This rift shoulder volcanic complex is characterised by open fissures and small $(<5 \mathrm{~m})$ recent fault scarps (Medynski et al., 2015). A combination of lava-flow surface and fault-scarp exposure dating gives consistent slip rates of $0.34-0.35 \mathrm{~mm} / \mathrm{yr}$ (Fig. 4C) for these faults, which are associated with the current off-axis highintensity magmatic phase (Medynski et al., 2015). These slip rates are much lower than those determined for the equivalent period in the axial graben (where the slip rates as high as $2.8 \mathrm{~mm} / \mathrm{yr}$ were measured).

\section{Recurrence timescale of September 2005-type dike intrusion}

Our field observations and scarp dating have allowed us to place constraints on the development of the two specific faults in the northern portion of the segment: Dikika-3 and Dikika-1 (Fig. 2A and Fig. 4). These west-dipping faults are separated by a $50-\mathrm{m}$ deep graben that is bounded by the east-dipping Dikika-3 fault on its western border (Fig. 2 and Fig. 5). This small graben is not observed in any other location along the rift, and its position along the eastern rift shoulder suggests that it might be related to off-axis intrusion of the type observed in September 2005 
TOPOGRAPHIC DEVELOPMENT

OF THE DMH RIFT UNDER THE INFLUENCE

OF MULTIPLE MAGMA RESERVOIRS

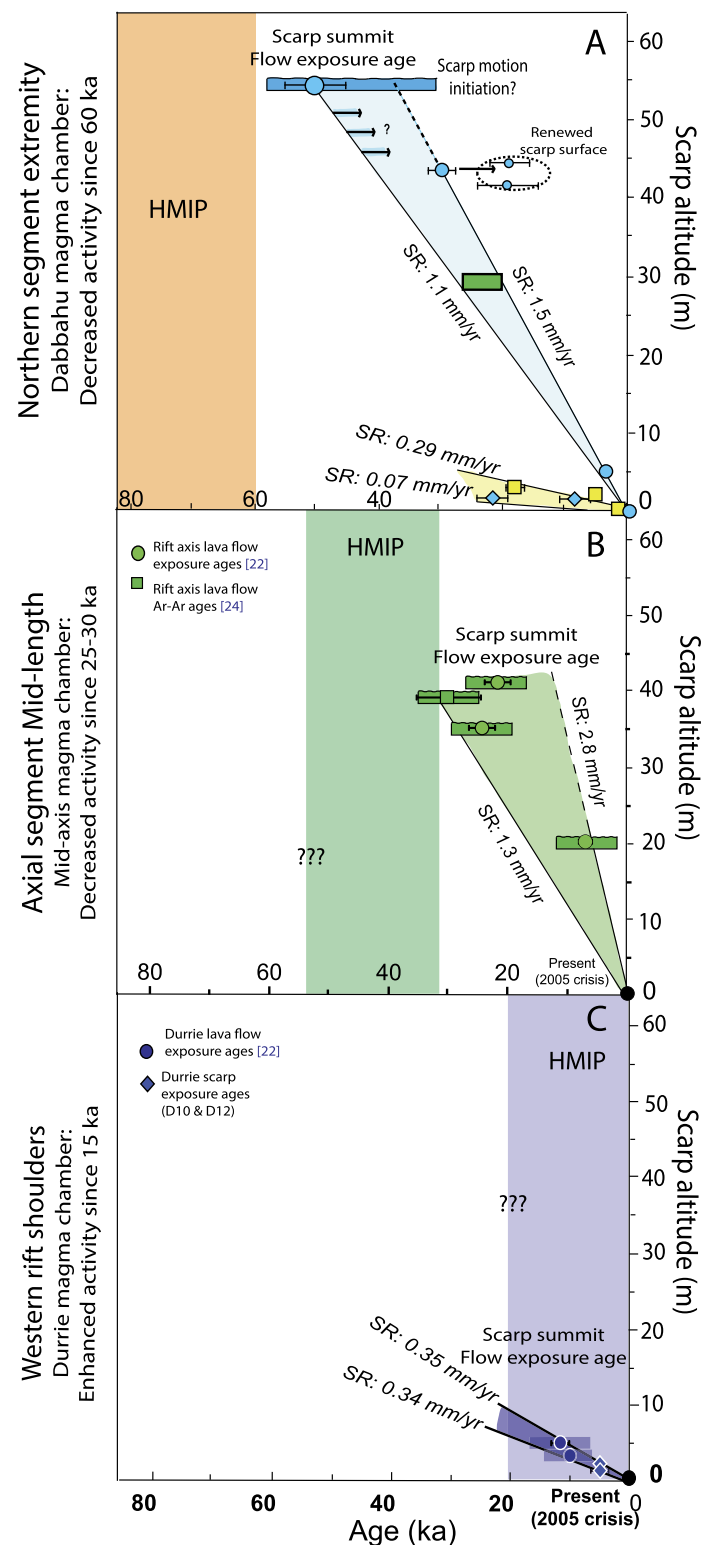

\section{ON AXIS TOPOGRAPHY DEVELOPMENT Northern part}

Assymmetrical and heterogeneous growth

$\begin{array}{ll}\triangle \text { Gab B scarp } & \diamond \text { Yem } 7 \& \text { Gab G3 } \square \text { Dikika } 1 \text { scarp: lava } \\ \text { o Gab A (Gabbole) } & \text { on top of the scarp }\end{array}$

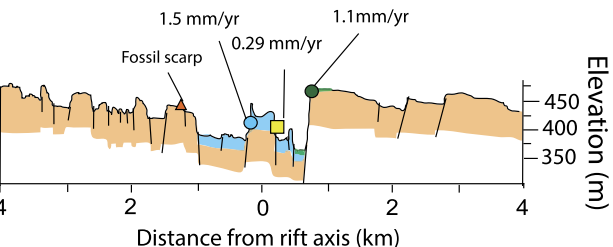

ON AXIS TOPOGRAPHY DEVELOPMENT

Central part

Symmetrical and homogeneous growth

Volcanism ages ranging from 30 to $7 \mathrm{ka}$

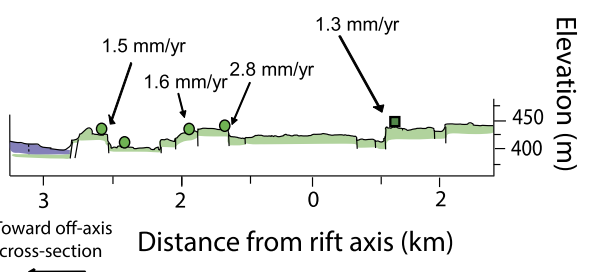

OFF-AXIS TOPOGRAPHY DEVELOPMENT

Limited growth of open fractures and small scarps

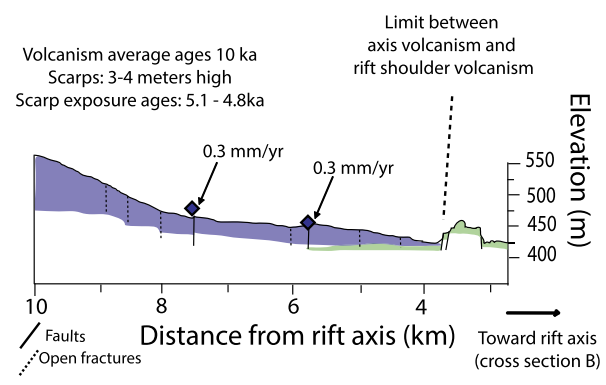

HMIP: High magma input phase

SR: Slipping Rate

??? Indicate the unknown age of the beginning of the HMIP

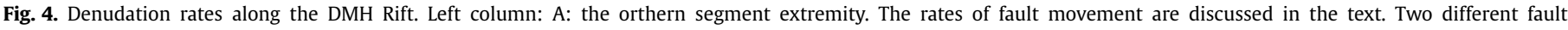

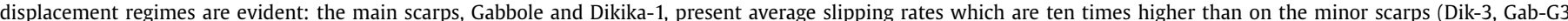

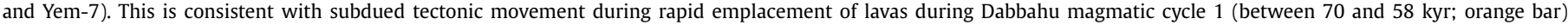

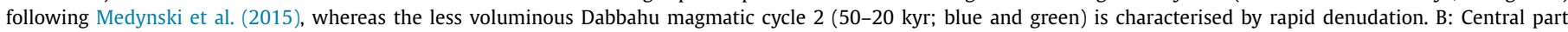

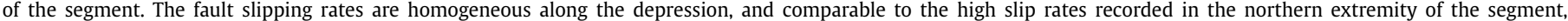

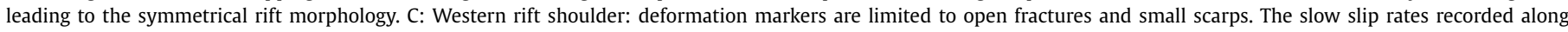

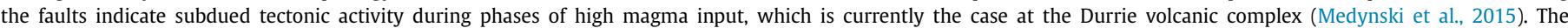

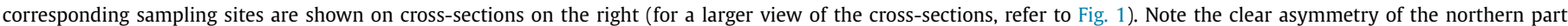

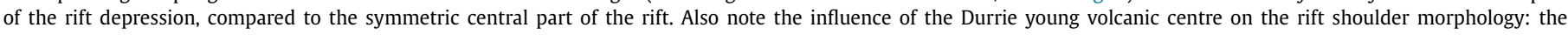

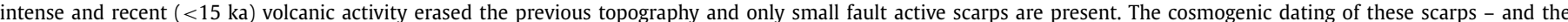

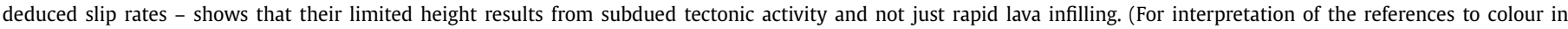
this figure legend, the reader is referred to the web version of this article.)

(Figs. 2 and 6A). The 8 m-high Dikika-3 scarp (DIK-3, Figs. 3A and 4) played a major role during the September 2005 intrusion, accommodating most of the deformation that occurred in the northern portion of the rift (Fig. 2, Wright et al., 2006; Rowland et al., 2007; Ebinger et al., 2008; Grandin et al., 2009). Geodetic measurements have shown that the faults above the September 2005 dike, particularly DIK-3 and to a lesser extent the Dikika-1 fault, continued to slip in the months following this first main intrusion as a result of magma draining out of Dabbahu deep reservoir and into the path of the September 2005 dike (Ebinger et al., 2008; Grandin et al., 2009; Dumont et al., 2016). In contrast, much larger scarps closer to the axis (e.g. the $65 \mathrm{~m}$ GABBOLE scarp, $350 \mathrm{~m} \mathrm{~W}$ 

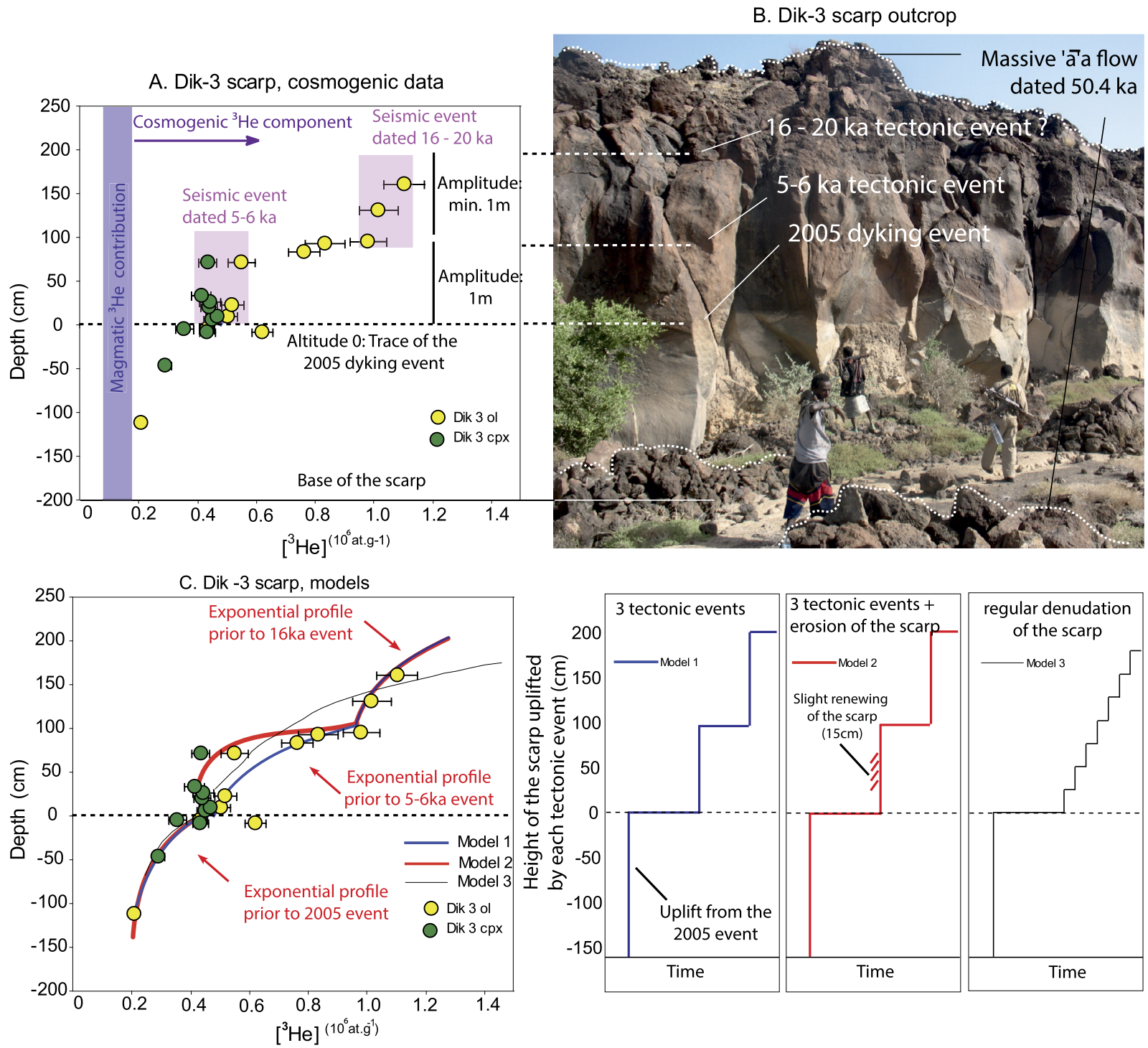

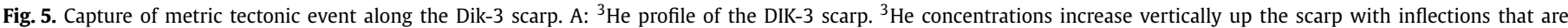

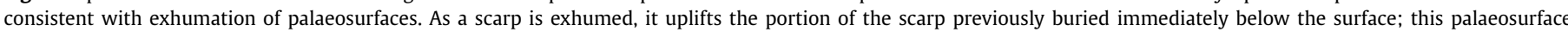

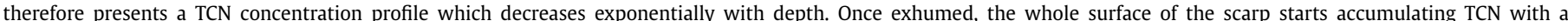

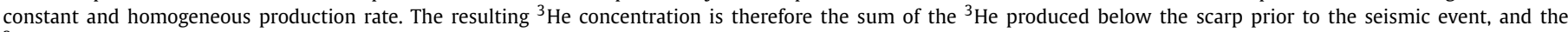

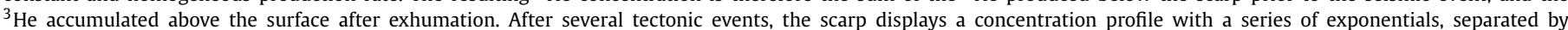

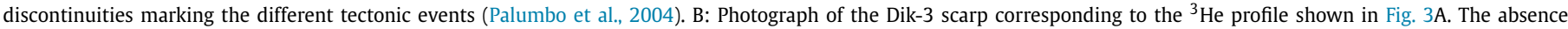

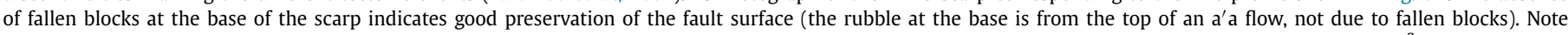

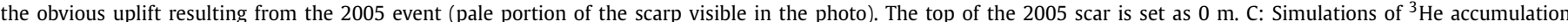

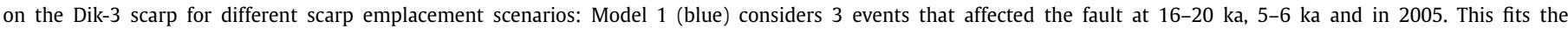

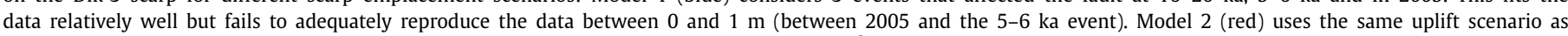

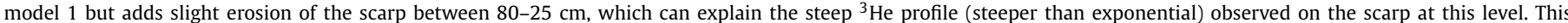

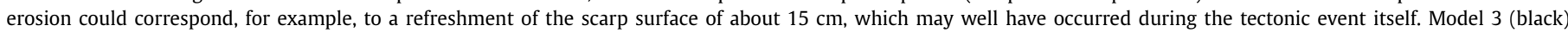

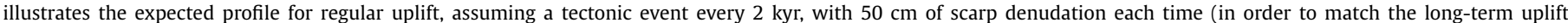

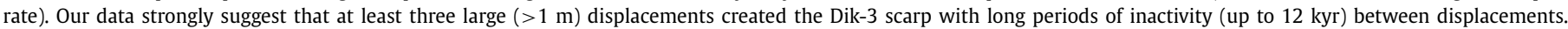

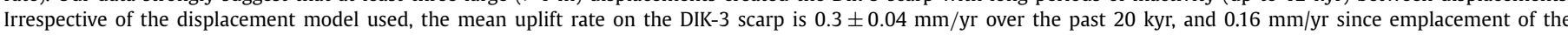
dissected lava. (For interpretation of the references to colour in this figure legend, the reader is referred to the web version of this article.)

of DIK-3; Fig. 3A) show little or no evidence for displacement in 2005 (Figs. 3A and 4 and SOM 1). This is almost certainly due to their distance from the dike and, in the case of GABBOLE, its westdipping orientation, i.e. away from the dike, which is unfavourable to accommodation of the dike-induced stresses.

To investigate the past recurrence of events similar to the September 2005 intrusion, we have reconstructed the displacement history of the Dik-3 fault using cosmogenic ${ }^{3} \mathrm{He}$ concentrations measured on a continuous vertical profile along the wellpreserved Dik-3 scarp (Fig. 5). The concentrations increase up the face of the scarp, with well-defined inflections in the profile that are consistent with multiple episodes of fault movement (Fig. 5). In the scarp section uplifted during the 2005 event (recognisable by a white horizontal stripe present on the scarp-face; Fig. 5), there is an exponential increase in ${ }^{3} \mathrm{He}$ concentration over $\sim 1 \mathrm{~m}$; this is the fossil attenuation profile which was buried prior to 2005 and was only exposed by the 2005 fault movement. Two similar exponential profiles are visible further up the scarp, corresponding to two earlier slip events. These two events both also produced $>1 \mathrm{~m}$ vertical movement on the scarp (Fig. 5), similar in amplitude to the 2005 event. These three tectonic events can be modelled by: i) a $2 \mathrm{~m}$ slip in 2005, ii) a $1 \mathrm{~m}$ slip at 5-6 kyr bp and iii) an event of 

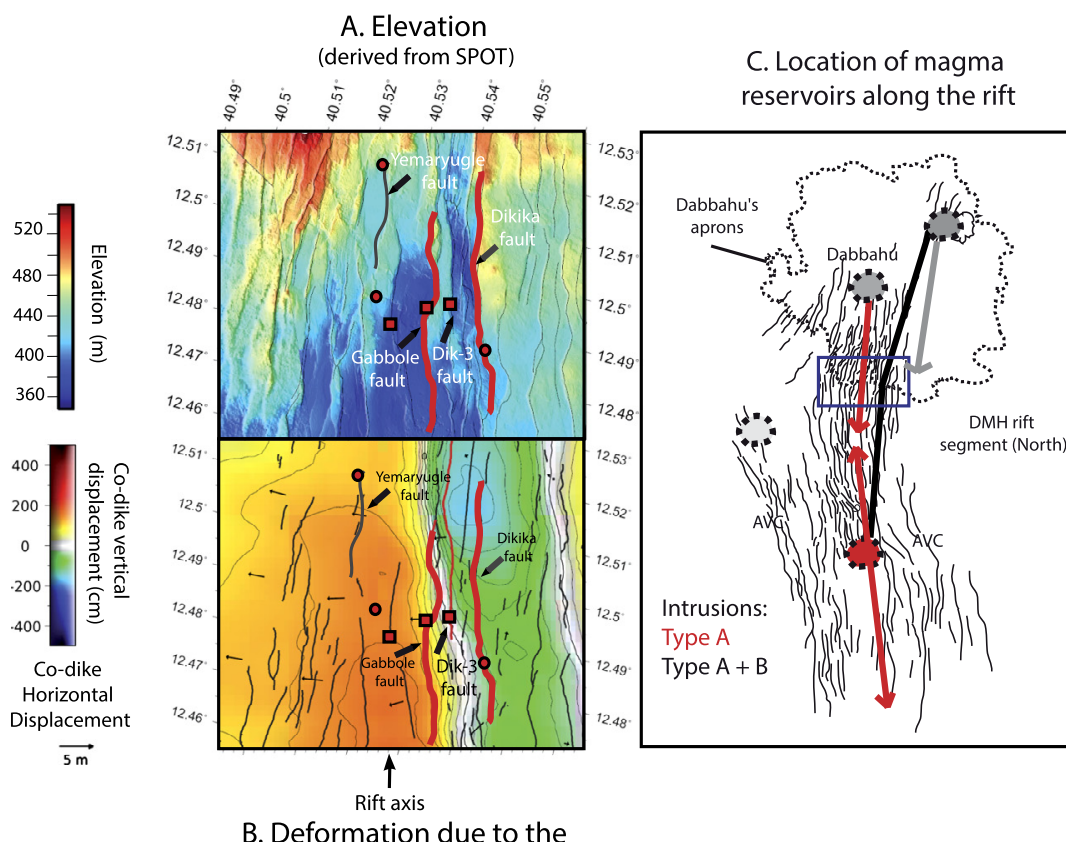

C. Location of magma
reservoirs along the rift

D. Local impact of secondary magma reservoirs on axial topography development

September 2005 intrusion

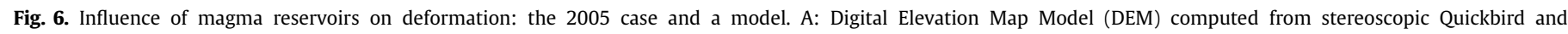

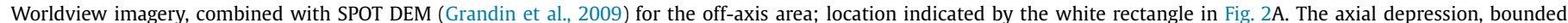

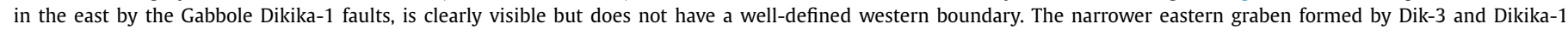

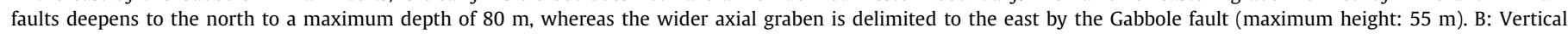

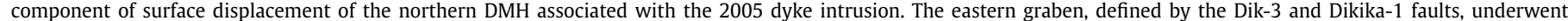

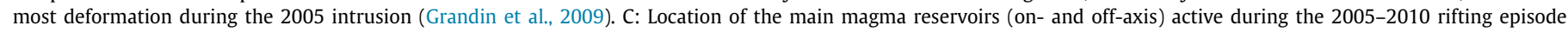

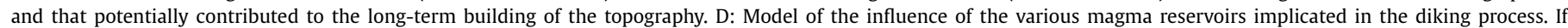

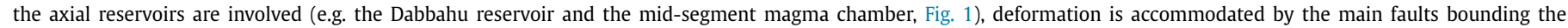

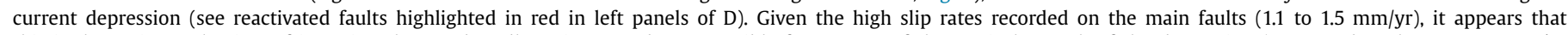

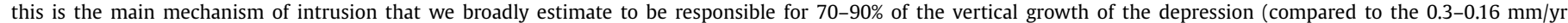

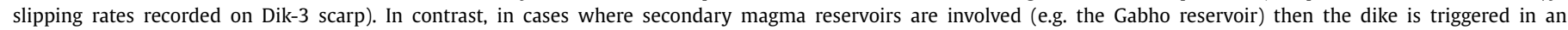

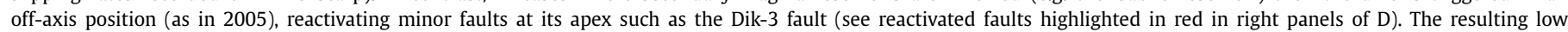

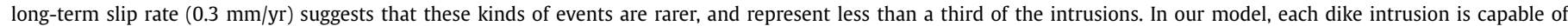

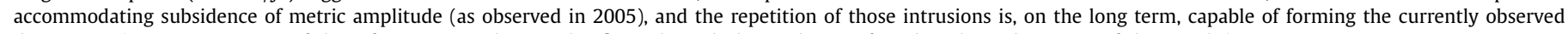
depression. (For interpretation of the references to colour in this figure legend, the reader is referred to the web version of this article.)

$>1 \mathrm{~m}$ at 16-20 kyr bp (see Fig. 4). The "plateau" in the ${ }^{3} \mathrm{He}$ profile (i.e. the large increase in $\left[{ }^{3} \mathrm{He}\right]$ over a small height interval) indicates that little or no slip occurred between these two seismic events; the Dik-3 fault was frozen for $\sim 10 \mathrm{kyr}$ between slip 2 and slip 3. Further details concerning age calculations are given in Fig. 5 and SOM 7. The calculated average vertical slip rate on the Dik-3 fault is $0.3 \mathrm{~mm} / \mathrm{yr}$ over the past $20 \mathrm{kyr}$. Since the emplacement of the dissected lava flow (51.1 $\pm 5 \mathrm{ka}$; Medynski et al., 2015), the average slip rate has been $0.16 \mathrm{~mm} / \mathrm{yr}$.

A $0.3-0.16 \mathrm{~mm} / \mathrm{yr}$ long-term slip on the Dik-3 fault could not have built the topography of the axial depression in the time available; taking the highest inferred slip rate, the $\sim 50 \mathrm{~m}$ high scarp would require activation no later than $166 \mathrm{ka}$, which is inconsistent with the age of the lava flow (51.1 $\pm 5 \mathrm{kyr}$; Medynski et al., 2015) cut by the Gabbole fault (Medynski et al., 2013). Although the DIK-3 fault is located close to the GABBOLE fault and cuts the same lava flow, the two faults have not been affected by the same mechanisms.

\section{The relationship between axial topography development and magma supply}

We propose a model in which the position and activity of magmatic reservoirs is fundamental in controlling the time-integrated development of rift topography.

Three magmatic centres have the potential to produce dikes at the axis of the DMH segment: the Dabbahu and Gabho volcanoes in the north and the mid-segment magma chamber in the central part of the segment (Fig. 1B). Recent studies have shown that magma injections in the crust are the main actors of extension in rift zones where magma is present like Afar or the Juan de Fuca ridge (Keir et al., 2009; Carbotte et al., 2006), which implies that dike-induced deformation should constitute a major process in the building of the topography in these environments. Dikes that are able to induce surface deformation do indeed produce focused fault reactivation above, with the majority of the deformation propagating upward on the plane of the dike (Rubin, 1992; Buck et al., 2005; Behn et al., 2006; Qin and Buck, 2008; Ito and Behn, 2008; Grandin et al., 2009; Dumont et al., 2016) (Fig. 6A and B). The axial depression should similarly reflect the dynamics and locations of dike intrusions. In the central part of the DMH, the depression is symmetrical with conjugate bounding scarps on either side of the graben and uniform slip rates, suggesting a homogeneous distribution of the dike injections (Figs. 1 and 5B). However, in the northern $\mathrm{DMH}$, the rift axis is asymmetrical and border faults on the western flank (what would be the equivalents of the Gabbole and Dikika- 1 faults east of the axis) are either absent or not clearly expressed in the topography (Fig. 4A). Instead, deformation is accommodated on eastern escarpment faults (Gabbole and Dikika-1) with high slip rates $(\sim 1.5 \mathrm{~mm} / \mathrm{yr})$ compared to those of the smaller, rarely activated axial scarps (equivalent to $0.15 \mathrm{~mm} / \mathrm{yr}$ slip rates - Gab-G3, Dik-3 and Yem-7 - Fig. 4A). We propose that this bimodal distribution of strain results from two different intrusion mechanisms: 1) dike injection along the axial depression from the MSMC and/or 
the Dabbahu magma reservoirs (Figs. 1 and 6C and D); and 2) dike injection due to complex interactions between the axial magmatic sources and the off-axis Gabho reservoir to the NE. The September 2005 intrusion is an example of the second, having started with the joint activity of the Dabbahu and Gabho reservoirs and only later involving the MSMC (Ayele et al., 2009; Wright et al., 2006, 2012; Grandin et al., 2009, 2010a, 2010b; Keir et al., 2011; Ebinger et al., 2008; Figs. 1 and 6C and D). In contrast, the 13 subsequent smaller dikes, fed by only the MSMC, result from the first mechanism. The second mechanism is also consistent with our observations concerning the building of the DIK-3 scarp. This scarp has an average slip rate that is only a fifth of that of the major faults (Gabbole and Dikika) but which accommodated the most deformation in 2005 because of both its vicinity to the off-axis dike intrusion and its east-dipping orientation, which is favourable to the release of stresses induced by an off-axis dike (Grandin et al., 2009; Dumont et al., 2016). Our results show that this particular fault is reactivated during tectonic events of at least metric amplitude (i.e., comparable to the September 2005 intrusion) every 5-10 kyr (Fig. 5). Because of its location (W border of a small, deep graben along the E edge of the rift), the DIK-3 fault is likely only reactivated during events comparable to the September 2005 off-axis intrusion, which resulted from interaction between the Dabbahu and Gabho magma chambers. The ages obtained for the DIK-3 scarp imply that off-axis intrusions like that of September 2005 are relatively infrequent events. The rift-axis topography, dominated by the Gabbole and Dikika faults which slip at a rate five-times faster than the DIK-3 fault, most likely developed under the influence of dike intrusions emplaced below the axial depression, without any contribution from off-axis magma chambers (Fig. 6). To reach the faster slip rate of $1.5 \mathrm{~mm} / \mathrm{yr}$ average, it is reasonable to assume that dikes were intruded more frequently along the axis than they were off axis. We propose that the rift asymmetry observed in the north therefore reflects the magmatic activity of the different magma reservoirs distributed along the rift over the long term. This topography arises as a consequence of dike injection from multiple shallow reservoirs, and not from a single focused emission point.

The 2005 rifting event resulted from the least frequently operating mechanism, the 3-reservoir mode of injection, which has a recurrence interval of once every 6-10 ka (Fig. 5). This is too infrequent to have built the observed off-axis topography. Most of the dyke injections that produced the axial graben of the DMH segment were intruded from the two axial reservoirs along the rift axis (Dabbahu and the MSMC). Given the relative slip rates on the Dik-3 fault (mainly reactivated during off-axis magma intrusions) and main Gabbole fault (mainly reactivated during on-axis intrusions), only about a tenth to a third of the intrusions were of the 2005 type (Fig. 6C).

The topography along the entire length of the DMH segment, was built after phases of intense volcanic activity ("HMIP periods" on Figs. 4 and 7). During intense magmatic activity, dikes were able to reach the surface and continuously feed lava flows, erasing any contemporaneously created topographic steps (Fig. 7A). The axial depression started to appear only after cessation of predominantly effusive volcanism (Fig. 7B), at about $40 \mathrm{ka}$ in the north and $20 \mathrm{ka}$ close to the centre of the segment, with identical mean slipping rates (1.1-1.5 mm/yr) occurring on the main bounding faults.

Furthermore, the early (pre-graben) phases of intense magmatic activity can be directly related to the magmatic cycles of the two reservoirs concerned (Dabbahu volcano and MSMC; Medynski et al., 2013). In the northern portion of the segment, the development of significant axial topography can be seen in the immediate vicinity of each reservoir to have corresponded directly to a phase of magma differentiation; when transfer of fresh, mantlederived liquids to the shallow reservoirs was limited, deforma-
A) new input of magma in the crust with high rate of surface eruptions ( 20-30 ka)

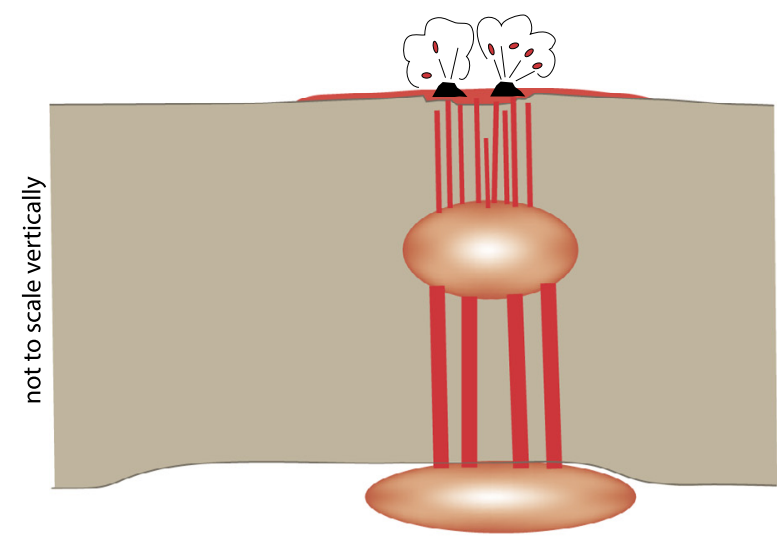

B) Progressive magma differentiation and development of the axial valley $(20-30 \mathrm{ka})$

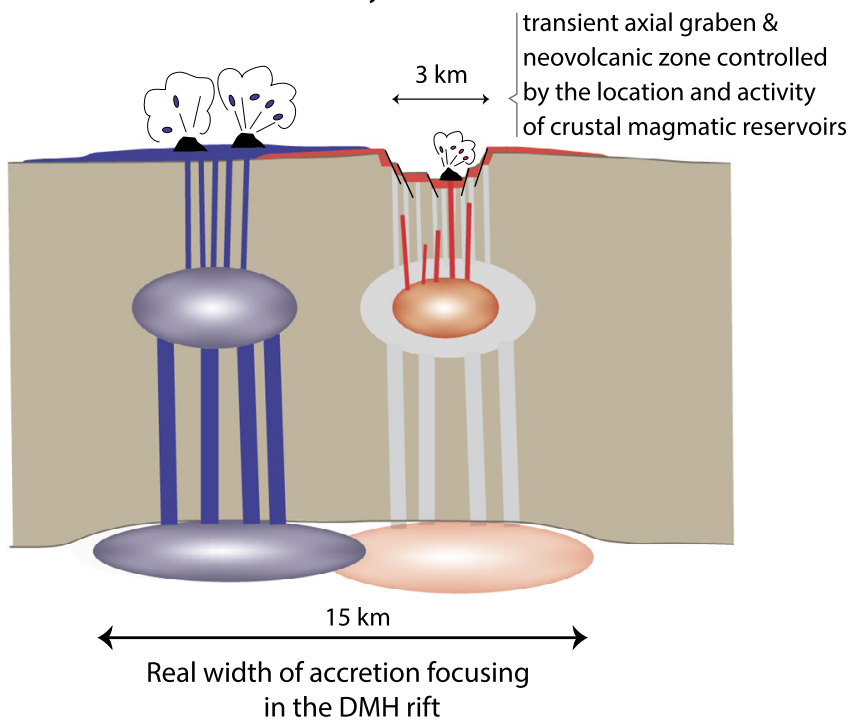

Fig. 7. Model for the evolution of the DMH rift in Central Afar. A: Initial phase of magma input into the crust from the crust-mantle boundary. Replenishments of mid crustal reservoir(s) (schematically represented on the cartoon) are continuous, and dikes frequently reach the surface and trigger high eruption rates. Extension is mostly accommodated by magma injection through the entire thickness of the crust. This phase of the magmatic cycle typically lasts for $\sim 20-30 \mathrm{kyr}$ (Medynski et al., 2013, 2015) and is characterised by major resurfacing and the absence of a significant axial graben. B: When the magma supply is limited, replenishment of the mid-crustal reservoir(s) stops and progressive differentiation of the residual liquid commences. There is reduced availability of magma in the upper crust and this, more differentiated, magma is more viscous; consequently, dike injections are less frequent and rarely reach the surface. Injections of mostly blind dikes trigger enhanced faulting and associated higher slip rates at the surface expressions of the faults. This phase of the magmatic cycle is characterised by the development of a narrow axial valley. Limited volumes of volcanic products are restricted to the growing axial graben, for which the width is directly controlled by the zone of dike injection. The occurrence of an axial topographic depression is transient and intimately linked to the location and activity of crustal magma reservoirs. For the DMH rift in Central Afar, the total width of magmatic accretion is therefore certainly not expressed by these narrow $(<3-5 \mathrm{~km})$ transient rift morphologies. It is instead represented by a wider zone ( $\sim 15 \mathrm{~km})$ constrained by the spatial distribution of the various ephemeral magmatic reservoirs. (For interpretation of the colours in this figure, the reader is referred to the web version of this article.)

tion was at its maximum (Field et al., 2012; Medynski et al., 2015). We can infer that the reduction in volume and increase in viscosity of the magmatic liquids resulted in dikes that rarely reached the surface, meaning that vertical faulting was required to accommodate the extension (Rubin, 1992; Buck et al., 2005; Behn et al., 2006; Qin and Buck, 2008; Ito and Behn, 2008; Grandin et al., 2009), and/or that the mechanical proprieties of the 
crust became less favourable for the production of dikes able to induce fault reactivation at the surface. This is demonstrated in the central DMH segment, where low $(0.35 \mathrm{~mm} / \mathrm{kyr}$, Fig. $4 \mathrm{C})$ slip rates were synchronous with intense off-axis basaltic magmatism at Durrie (Medynski et al., 2015), whereas over the same period, high slip rates (up to $2.8 \mathrm{~mm} / \mathrm{yr}$; Fig. 4B) occurred in the adjacent, magma-starved graben where the differentiated basalts were erupted (Medynski et al., 2015).

\section{Rift zone activity through time and magmatic accretion}

The Afar rift system has not yet achieved full continental breakup and cannot be considered a mature spreading ridge. Magmatic accretion in this nascent spreading centre developing within the remnants of continental lithosphere is likely controlled by the distribution of melt at the top of the upwelling mantle (Hammond et al., 2013; Rychert et al., 2012). In the DMH rift system, where the magma supply is typical of an slow- to intermediate-spreading centre, it appears that the topography of the axial rift valley is transient and is expressed only when the magma available in the reservoirs decreases (see Fig. 7; fault slip rates increase when the magmatic activity decreases). The absence of tilting on the rift margins over the last $200 \mathrm{kyr}$ also suggests that amagmatic accommodation of extension was not required for fault activation over this time period. Furthermore, if no magma was required in the $\mathrm{DMH}$, major faulting would occur, cutting the whole lithosphere and not just the region above an intruding dike, and the resulting faults/deformation/reactivated faulting would be distributed over a wider area. Thus, extension in the DMH segment is instead accommodated by dikes injected laterally from multiple ephemeral reservoirs (Medynski et al., 2015) located along its length, and we can link the topography growth to repeated intrusions such as the 2005-one over the long term. This study demonstrates that the location and development of narrow axial valleys is fundamentally controlled by the spatial and temporal interplay between these various magmatic reservoirs, and that tectonic activity is subaerially expressed as a result of the decreased volcanic activity. We interpret the reduction in volcanic activity to be the result of magma differentiation and a progressive decrease in the magmatic activity of a magma reservoir (possibly associated with changes in the distribution of stress in the lithosphere), leading to fewer dike injections or injection of dikes that cannot reach the surface, and thus requiring faulting to accommodate extension at the surface (Fig. 7). When magma supply is sustained by stable magma chambers below an active rift segment over a few tens of kyr (as in Afar and at intermediate to fast spreading ridges), the axial topography of rifts can be entirely controlled by the magmatic reservoirs. Therefore, the axial topography only represents the surface deformations by diking processes.

The present spreading rate in central Afar is within the range considered for slow-spreading ridges $(\sim 1.5 \mathrm{~mm} / \mathrm{yr}$, McClusky et al., 2010; Calais et al., 2006). However, the DMH segment also shares characteristics with intermediate ridges such as the Juan de Fuca ridge (MacDonald and Atwater, 1978; Carbotte et al., 2001, 2006; Macdonald, 2001; Macdonald et al., 2005; Wright et al., 2012) with its $50-200 \mathrm{~m}$ deep, 1-8 $\mathrm{km}$ wide axial valley. Magma bodies have been identified at comparable depths $(\sim 2 \mathrm{~km})$ at the Juan de Fuca ridge, even below segments that are thought to be in a purely tectonic phase (Carbotte et al., 2006). To explain this, Carbotte et al. (2006) put forward a model in which the evolving axial topography results from feedback between the rheology of the crust above magma sills and dike intrusions, rather than from episodic magma delivery from the mantle.

Our data strongly support this model, and demonstrate significant advantages to be gained from using onshore analogues to better understand MOR processes.

\section{Acknowledgements}

This paper is dedicated to the memory of our friend, colleague and mentor, Pete Burnard who passed away too early in a tragic accident. We are grateful to Barbara Hoffman (Afar Rift Consortium) for providing LiDAR images and J.I. Seid for his help in the field, as well as the members of the Afar regional government at Semera. We are grateful to B. Tibari (CRPG) for assistance with cosmogenic ${ }^{3} \mathrm{He}$ and $U$ and Th measurements and L. Zimmerman (CRPG) for technical assistance with mass spectrometry. We would like to thank Prof. Gudmundsson and Prof. R. Buck for their careful and constructive reviews. This study has been supported by funds from the French consortium "Action Marges". CVB publishes with permission of the Executive Director of the British Geological Survey (Natural Environment Research Council). This is CRPG contribution \# 2445. This is IPGP contribution \# 3739.

\section{Appendix A. Supplementary material}

Supplementary material related to this article can be found online at http://dx.doi.org/10.1016/j.epsl.2016.04.014.

\section{References}

Ayele, A., Keir, D., et al., 2009. September 2005 mega-dike emplacement in the Manda-Harraro nascent oceanic rift (Afar depression). Geophys. Res. Lett. 36 (20)

Barisin, I., et al., 2009. Surface displacements in the September 2005 Afar rifting event from satellite image matching: asymmetric uplift and faulting. Geophys. Res. Lett. 36 (7)

Behn, M.D., Buck, W.R., Sacks, I.S., 2006. Topographic controls on dike injection in volcanic rift zones. Earth Planet. Sci. Lett. 246 (3-4), 188-196.

Belachew, M., Ebinger, C., et al., 2011. Comparison of dike intrusions in an incipient seafloor-spreading segment in Afar, Ethiopia: seismicity perspectives. J. Geophys. Res. 116 (B6), B06405.

Biggs, J., Amelung, F., Gourmelen, N., Dixon, T.H., Kim, S.W., 2009. InSAR observations of 2007 Tanzania rifting episode reveal mixed fault and dyke extension in an immature continental rift. Geophys. J. Int. 179 (1), 549-558.

Blard, P.-H., Lave, J., Sylvestre, F., et al., 2013. Cosmogenic He-3 production rate in the high tropical Andes ( $3800 \mathrm{~m}, 20$ degrees S): implications for the local last glacial maximum. Earth Planet. Sci. Lett. 377, 260-275.

Brandsdottir, B., Einarsson, P., 1979. Seismic activity associated with the September 1977 deflation of the Krafla central volcano in northeastern Iceland. J. Volcanol. Geotherm. Res. 6 (3-4), 197-212.

Buck, W.R., 2006. The role of magma in the development of the Afro-Arabian Rift System. Geol. Soc. (Lond.) Spec. Publ. 259 (1), 43-54.

Buck, W.R., Lavier, L.L., Poliakov, A.N.B., 2005. Modes of faulting at mid-ocean ridges. Nature 434 (7034), 719-723.

Calais, E., Ebinger, C.J., Hartnady, C., Nocquet, J.M., 2006. Kinematics of the East African Rift from GPS and earthquake slip vector data. In: Special Publication Geological Society of London, vol. 259, p. 9.

Calais, E., d'Oreye, N., Albaric, J., Deschamps, A., Delvaux, D., Déverchere, J., Oyen, A., 2008. Strain accommodation by slow slip and dyking in a youthful continental rift, East Africa. Nature 456 (7223), 783-787.

Carbotte, S.M., et al., 2001. Mid-ocean ridge seismic structure. In: Encyclopedia of Ocean Sciences, second edition. Academic Press, Oxford, pp. 826-836.

Carbotte, S.M., Detrick, R.S., Harding, A., Canales, J.P., Babcock, J., Kent, G., Diebold, J., 2006. Rift topography linked to magmatism at the intermediate spreading Juan de Fuca Ridge. Geology 34 (3), 209-212.

Doubre, C., Peltzer, G., 2007. Fluid-controlled faulting process in the Asal Rift, Djibouti, from 8 yr of radar interferometry observations. Geology 35 (1), 69-72.

Dumont, S., Socquet, A., Grandin, R., Doubre, C., Klinger, Y., 2016. Surface displacements on faults triggered by slow magma transfers between dyke injections in the 2005-2010 rifting episode at Dabbahu-Manda-Hararo rift (Afar, Ethiopia). Geophys. J. Int. 204 (1), 399-417. http://dx.doi.org/10.1093/gji/ggv449.

Dunai, T.J., Wijbrans, J.R., 2000. Long-term cosmogenic ${ }^{3} \mathrm{He}$ production rates (152 ka-1.35 Ma) from ${ }^{40} \mathrm{Ar} /{ }^{39} \mathrm{Ar}$ dated basalt flows at $29^{\circ} \mathrm{N}$ latitude. Earth Planet. Sci. Lett. 176 (1), 147-156.

Ebinger, C., et al., 2010. Length and timescales of rift faulting and magma intrusion: the Afar rifting cycle from 2005 to present. Annu. Rev. Earth Planet. Sci. 38 (1), 439-466.

Ebinger, C.K., Ayele, A., Calais, E., Wright, T.J., Belachew, M., Hammond, J.O.S., Campbell, E., Buck, W.R., 2008. Capturing magma intrusion and faulting processes during continental rupture: seismicity of the Dabbahu (Afar) rift. Geophys. J. Int. http://dx.doi.org/10.1111/j.1365-246X.2008.03877.x. 
Einarsson, P., 1991. Earthquakes and present-day tectonism in Iceland. Tectonophysics 189, 261-279.

Field, L., et al., 2012. Magma storage conditions beneath Dabbahu Volcano (Ethiopia) constrained by petrology, seismicity and satellite geodesy. Bull. Volcanol., 1-24.

Foeken, J.P.T., Day, S., Stuart, F.M., 2009. Cosmogenic ${ }^{3}$ He exposure dating of the Quaternary basalts from Fogo, Cape Verdes: implications for rift zone and magmatic reorganisation. Quat. Geochronol. 4 (1), 37-49.

Forslund, T., Gudmundsson, A., 1991. Crustal spreading due to dikes and faults in southwest Iceland. J. Struct. Geol. 13, 443-457.

Froger, J.L., Fukushima, Y., Briole, P., Staudacher, T., Souriot, T., Villeneuve, N., 2004. The deformation field of the August 2003 eruption at Piton de la Fournaise, Reunion Island, mapped by ASAR interferometry. Geophys. Res. Lett. 31 (14).

Goehring, B.M., Kurz, M.D., et al., 2010. A reevaluation of in situ cosmogenic ${ }^{3} \mathrm{He}$ production rates. Quat. Geochronol. 5 (4), 410-418.

Gosse, J.C., Phillips, F.M., 2001. Terrestrial in situ cosmogenic nuclides: theory and application. Quat. Sci. Rev. 20 (14), 1475-1560.

Grandin, R., et al., 2010a. Seismicity during lateral dike propagation: insights from new data in the recent Manda Hararo-Dabbahu rifting episode (Afar, Ethiopia). Geochem. Geophys. Geosyst. 12, Q0AB08.

Grandin, R., et al., 2010b. Transient rift opening in response to multiple dike injections in the Manda Hararo rift (Afar, Ethiopia) imaged by time-dependent elastic inversion of interferometric synthetic aperture radar data. J. Geophys. Res. 115 (B9), B09403.

Grandin, R., et al., 2012. Elastic thickness control of lateral dyke intrusion at midocean ridges. Earth Planet. Sci. Lett. 319, 83-95.

Grandin, R., Socquet, A., Binet, R., Klinger, Y., Jacques, E., de Chabalier, J.-B., King, G.C.P., Lasserre, C., Tait, S., Tapponnier, P., Delorme, A., Pinzuti, P., 2009. September 2005 Manda Hararo-Dabbahu rifting event, Afar (Ethiopia): constraints provided by geodetic data. J. Geophys. Res. 114, B08404. http://dx.doi.org/10.1029/ 2008JB005843.

Gudmundsson, A., 2003. Surface stresses associated with arrested dykes in rift zones. Bull. Volcanol. 65 (8), 606-619.

Gudmundsson, A., 2005. Effects of mechanical layering on the development of normal faults and dykes in Iceland. Geodin. Acta 18 (1), 11-30.

Gudmundsson, A., Philipp, S.L., 2006. How local stress fields prevent volcanic eruptions. J. Volcanol. Geotherm. Res. 158 (3), 257-268.

Hamling, I.J., Ayele, A., Bennati, L., Calais, E., Ebinger, C.J., Keir, D., et al., 2009. Geodetic observations of the ongoing Dabbahu rifting episode: new dyke intrusions in 2006 and 2007. Geophys. J. Int. 178 (2), 989-1003.

Hammond, J.O.S., Kendall, J-M., Stuart, G.W., Ebinger, C.J., Bastow, I.D., Keir, D., Ayele, A., Belachew, M., Goitom, B., Ogubazghi, G., Wright, T.J., et al., 2013. Mantle upwelling and initiation of rift segmentation beneath the Afar Depression. Geology (ISSN 0091-7613) 41, 635-638.

Ito, G., Behn, M.D., 2008. Magmatic and tectonic extension at mid-ocean ridges: 2. Origin of axial morphology. Geochem. Geophys. Geosyst. 9 (9), Q09012.

Keir, D., Hamling, I.J., Ayele, A., Calais, E., Ebinger, C., Wright, T.J., et al., 2009. Evidence for focused magmatic accretion at segment centers from lateral dike injections captured beneath the Red Sea rift in Afar. Geology 37 (1), $59-62$

Keir, D., et al., 2011. The magma-assisted removal of Arabia in Afar: evidence from dike injection in the Ethiopian rift captured using InSAR and seismicity. Tectonics 30 (2)

Licciardi, J.M., Pierce, K.L., 2008. Cosmogenic exposure-age chronologies of Pinedale and Bull. Lake glaciations in greater Yellowstone and the Teton Range, USA Quat. Sci. Rev. 27 (7-8), 814-831.

MacDonald, K.C., Atwater, T.M., 1978. Evolution of rifted ocean ridges. Earth Planet. Sci. Lett. 39 (3), 319-327.

Macdonald, K.C., 2001. Mid-ocean ridge tectonics, volcanism, and geomorphology. In: John, A., et al. (Eds.), Encyclopedia of Ocean Sciences, second edition. Academic Press, Oxford, pp. 852-866.
Macdonald, K.C., et al., 2005. TECTONICS | Mid-ocean ridges. In: Encyclopedia of Geology. Oxford, Elsevier, pp. 372-387.

Mastin, L.G., Pollard, D.D., 1988. Surface deformation and shallow dike intrusion processes at Inyo Craters, Long Valley, California. J. Geophys. Res., Solid Earth 93 (B11), 13221-13235.

McClusky, S., Reilinger, R., Ogubazghi, G., Amleson, A., Healeb, B., Vernant, P., et al. 2010. Kinematics of the southern Red Sea-Afar Triple Junction and implications for plate dynamics. Geophys. Res. Lett. 37 (5).

Medynski, S., et al., 2013. Controls on magmatic cycles and development of rift topography of the Manda Hararo segment (Afar, Ethiopia): insights from cosmogenic ${ }^{3} \mathrm{He}$ investigation of landscape evolution. Earth Planet. Sci. Lett. 367, 133-145.

Medynski, S., Pik, R., Burnard, P., Vye-Brown, C., France, L., Schimmelpfennig, I., Yirgu, G., 2015. Stability of rift axis magma reservoirs: spatial and temporal evolution of magma supply in the Dabbahu rift segment (Afar, Ethiopia) over the past 30 kyr. Earth Planet. Sci. Lett. 409, 278-289.

Niedermann, S., 2002. Cosmic-ray-produced noble gases in terrestrial rocks: dating tools for surface processes. Rev. Mineral. Geochem. 47 (1), 731-784.

Palumbo, L., et al., 2004. Slip history of the Magnola fault (Apennines, Central Italy) from ${ }^{36} \mathrm{Cl}$ surface exposure dating: evidence for strong earthquakes over the Holocene. Earth Planet. Sci. Lett. 225 (1-2), 163-176.

Qin, R., Buck, W.R., 2008. Why meter-wide dikes at oceanic spreading centers? Earth Planet. Sci. Lett. 265 (3-4), 466-474

Rowland, J., et al., 2007. Fault growth at a nascent slow-spreading ridge: 2005 Dabbahu rifting episode, Afar. Geophys. J. Int. 171. http://dx.doi.org/10.1111/ j.1365-246X.2007.03584.X.

Rubin, A.M., 1992. Dike-induced faulting and graben subsidence in volcanic rift zones. J. Geophys. Res., Solid Earth 97 (B2), 1839-1858.

Rubin, A.M., Pollard, D.D., 1988. Dike-induced faulting in rift zones of Iceland and Afar. Geology 16 (5), 413-417.

Rychert, C.A., Hammond, J.O., Harmon, N., Kendall, J.M., Keir, D., Ebinger, C., Stuart G., 2012. Volcanism in the Afar Rift sustained by decompression melting with minimal plume influence. Nat. Geosci. 5 (6), 406-409.

Schimmelpfennig, I., Benedetti, L., et al., 2009. Sources of in-situ ${ }^{36} \mathrm{Cl}$ in basaltic rocks. Implications for calibration of production rates. Quat. Geochronol. 4 (6), 441-461.

Schimmelpfennig, I., Benedetti, L., et al., 2011. Calibration of cosmogenic ${ }^{36} \mathrm{Cl}$ production rates from $\mathrm{Ca}$ and $\mathrm{K}$ spallation in lava flows from Mt. Etna $\left(38^{\circ} \mathrm{N}\right.$ Italy) and Payun Matru ( $36^{\circ} \mathrm{S}$, Argentina). Geochim. Cosmochim. Acta 75 (10) 2611-2632.

Sigmundsson, F., et al., 2015. Segmented lateral dyke growth in a rifting event at Bárdharbunga volcanic system, Iceland. Nature 517 (7533), 191-195.

Standish, J.J., Sims, K.W., 2010. Young off-axis volcanism along the ultraslowspreading Southwest Indian Ridge. Nat. Geosci. 3 (4), 286-292.

Stone, J.O., 2000. Air pressure and cosmogenic isotope production. J. Geophys. Res. Solid Earth 105 (B10), 23753-23759.

Vermeesch, P., 2007. CosmoCalc: an Excel add-in for cosmogenic nuclide calculations. Geochem. Geophys. Geosyst. 8, Q08003.

Vye-Brown, C. Medynski, S. et al., 2012 Geological map of the Dabbahu (MandaHararo) Rift, North, 1:100,000 scale. British Geological Survey.

White, S.M., Haymon, R.M., Carbotte, S., 2006. A new view of ridge segmentation and near-axis volcanism at the East Pacific Rise, 8-12N, from EM300 multibeam bathymetry. Geochem. Geophys. Geosyst. 7 (12).

Wright, T., Ebinger, C., Biggs, J., Ayele, A., Yirgu, G., Keir, D., Stork, A., 2006. Magmamaintained rift segmentation at continental rupture in the 2005 Afar dyking episode. Nature 442, 291-294.

Wright, T.J., et al., 2012. Geophysical constraints on the dynamics of spreading centres from rifting episodes on land. Nat. Geosci. 5 (4), 242-250.

Zreda, M.G., Phillips, F.M., et al., 1993. Cosmogenic ${ }^{36} \mathrm{Cl}$ dating of a young basaltic eruption complex, Lathrop Wells, Nevada. Geology 21 (1), 57-60. 